\title{
The effect of selected fungicides on the chemical composition of strawberry fruits and contamination with dithiocarbamate residues
}

\author{
Karol Wysocki*, Tadeusz, Banaszkiewicz
}

\author{
Department of Horticulture \\ University of Warmia and Mazury in Olsztyn \\ Prawocheńskiego 21, 10-956 Olsztyn
}

\begin{abstract}
In a four-year field experiment, fenhexamid, iprodione, pyrimethanil and thiram were applied in four different series as fungicides recommended for the control of grey mold (Botrytis cinerea) in strawberries. The plant protection products had no significant effect on the chemical composition of strawberry fruits of the Kent and Senga Sengana cultivars with the exception of an increase in the vitamin C level in 'Kent' strawberries. They also contributed to minor variations in the content of extract, total sugars, organic acids, polyphenols and anthocyanins. Dithiocarbamate residues were detected in all samples from the first harvest of strawberries that had been treated with the thiram fungicide.
\end{abstract}

Key words: Fragaria $\times$ ananassa; L-ascorbic acid; pesticides; thiram residues

\section{INTRODUCTION}

Strawberries (Fragaria $\times$ ananassa Duch.) are a widely grown species of berry fruit that are characterized by a high nutritional value and health benefits. Strawberries are low in calories and contain readily available carbohydrates, organic acids, vitamins, pectins and fiber (Hakala et al. 2003). The refreshing taste of strawberries can be attributed to their high water content. Recent research demonstrated that strawberries are a rich source of biologically active compounds, including vitamin $\mathrm{C}$ and antioxidants such as anthocyanins and polyphenols. L-ascorbic acid (vitamin C) in fruit plays the role of a natural antioxidant under exposure to environmental stressors. Anthocyanins and polyphenols are particularly valued on account of their anticarcinogenic, anti-inflammatory, neuroprotective and antisclerotic properties (Miller et al. 2008, Roussos et al. 2009). According to numerous studies, the chemical composition of strawberries can be modified subject to the cultivar, weather conditions and agricultural practices (Kalt et al. 1999, Kasperbauer et al. 2001, Skupień 2003, Ohtsuka et al. 2004, Kahu et al. 2010). The time elapsed between fruit harvest and refrigeration is also an important factor, and delayed refrigeration leads to the loss of nutritional value in strawberries (Nunes et al. 1995). It was found that pollination by insects enhances the nutritive value of fruits and plays a very important role in organic farming (Andersson et al. 2012, Bartomeus et al. 2014). So far, non-chemical plant protection methods are rarely used in strawberry production. It has

\footnotetext{
*Corresponding author.

Tel.: +48 8952334 50; fax: +48 8952333 32;

e-mail: karol.wysocki@uwm.edu.pl (K. Wysocki).
} 
been found that the use of fungicide applications affect organic compound accumulation in fruits to a lesser degree than other factors (Given 1985). Smith (2013) reported that fungicide treatment caused lower ellagic acid and resveratrol content in muscadine grape berries. This was the reason why fungicide applications can be considered to modify the chemical composition of strawberry fruits. The wide use of pesticides, in particular fungicides, contributes to the risk of the residual contamination of strawberries, which can lower their commercial value and consumer acceptance. According to Grosicka-Maciagg (2011), the residues of pesticides such as thiram, which break down slowly and stay in the environment for a long time, contaminate food and may cause adverse health effects. It is worth noting that the Maximum Residue Limits for thiram are different in many countries. For example, in Poland value of the MRL is $10 \mathrm{mg} \mathrm{kg}^{-1}$ (Regulation of Agriculture and Rural Development Minister 2008), in Canada it is $7 \mathrm{mg} \mathrm{kg}^{-1}$ (http://prrp.hc-sc.gc.ca/mrl-lrm/results-eng.php), in Egypt it is $5 \mathrm{mg} \mathrm{kg}^{-1}$ (Dogheim et al. 2001) and in Australia it is only $3 \mathrm{mg} \mathrm{kg}^{-1}$ (Keats 2013).

The objective of this study was to evaluate the effect of different fungicide protection levels on the chemical composition (a) and contamination with dithiocarbamate residues (b) of strawberry fruits. The experiment (a) was conducted in 2010-2012 using the Kent and Senga Sengana cultivars and (b) in 2011-2013 using the Senga Sengana cultivar.

\section{MATERIAL AND METHODS}

Field experiments were conducted in the Experimental Garden of the University of Warmia and Mazury in Olsztyn, on brown soil with 2.4\% organic matter content and a $\mathrm{pH}$ of 6.8-7.2 $\left(\mathrm{pH}_{\mathrm{H} 2 \mathrm{O}}\right)$. Mineral fertilizers were applied in line with standard recommendations based on an analysis of the chemical composition of the soil.

The experimental plot area was $5.1 \mathrm{~m}^{2}$. Twenty strawberry plants were grown in each plot. The experiment was performed in four replications. All crop protection products were used at the rates and on the dates indicated in the Polish strawberry protection program in force. The tested fungicides were applied using the Tytan backpack sprayer (10 1), with 5001 of water per ha. The fungicide treatments and their dosages are presented in Table 1. The overall dose of active substances in every fungicide

Table 1. Application terms and dosages of plant protection products in studied objects

\begin{tabular}{|c|c|c|c|c|c|c|}
\hline \multirow{2}{*}{ Treatments } & \multirow{2}{*}{$\begin{array}{l}\text { Plant protection products } \\
\text { and their dosages }\end{array}$} & \multirow{2}{*}{$\begin{array}{l}\text { Active } \\
\text { substance }\end{array}$} & \multicolumn{4}{|c|}{ Dates of treatments } \\
\hline & & & 2010 & 2011 & 2012 & 2013 \\
\hline I & - & - & - & - & - & - \\
\hline \multirow{3}{*}{ II } & $\begin{array}{l}\text { Thiram Granuflo } 80 \mathrm{WG} \\
4 \mathrm{~kg} \mathrm{ha}^{-1}\end{array}$ & $\begin{array}{l}\text { thiram } \\
3.2 \mathrm{~kg} \mathrm{ha}^{-1}\end{array}$ & 11.05 & 10.05 & 05.05 & 16.05 \\
\hline & $\begin{array}{l}\text { Rovral Flo } 255 \mathrm{SC} \\
\qquad 51 \mathrm{ha}^{-1}\end{array}$ & $\begin{array}{l}\text { iprodione } \\
1.271 \mathrm{ha}^{-1}\end{array}$ & 17.05 & 16.05 & 09.05 & 23.05 \\
\hline & $\begin{array}{l}\text { Teldor } 500 \mathrm{SC} \\
1.5 \mathrm{~h} \mathrm{ha}^{-1}\end{array}$ & $\begin{array}{l}\text { fenhexamid } \\
0.751 \mathrm{ha}^{-1}\end{array}$ & 09.06 & 05.06 & 29.05 & 10.06 \\
\hline \multirow{4}{*}{ III } & $\begin{array}{l}\text { Thiram Granuflo } 80 \mathrm{WG} \\
4 \mathrm{~kg} \mathrm{ha}^{-1}\end{array}$ & $\begin{array}{l}\text { thiram } \\
3.2 \mathrm{~kg} \mathrm{ha}^{-1}\end{array}$ & $11.05 ; 02.06$ & $10.05 ; 30.05$ & $05.05 ; 18.05$ & $16.05 ; 04.06$ \\
\hline & $\begin{array}{l}\text { Rovral Flo } 255 \mathrm{SC} \\
51 \mathrm{ha}^{-1}\end{array}$ & $\begin{array}{l}\text { iprodione } \\
1.27 \mathrm{ha}^{-1}\end{array}$ & 17.05 & 16.05 & 09.05 & 23.05 \\
\hline & $\begin{array}{l}\text { Mythos } 300 \mathrm{SC} \\
2.51 \mathrm{ha}^{-1}\end{array}$ & $\begin{array}{l}\text { pirymethanil } \\
0.831 \mathrm{ha}^{-1}\end{array}$ & 24.05 & 23.05 & 13.05 & 28.05 \\
\hline & $\begin{array}{l}\text { Teldor } 500 \mathrm{SC} \\
1.51 \mathrm{ha}^{-1}\end{array}$ & $\begin{array}{l}\text { fenhexamid } \\
0.751 \mathrm{ha}^{-1}\end{array}$ & 09.06 & 05.06 & 29.05 & 10.06 \\
\hline \multirow{3}{*}{ IV } & $\begin{array}{l}\text { Thiram Granuflo } 80 \mathrm{WG} \\
\qquad 4 \mathrm{~kg} \mathrm{ha}^{-1}\end{array}$ & $\begin{array}{l}\text { thiram } \\
3.2 \mathrm{~kg} \mathrm{ha}^{-1}\end{array}$ & - & 10.05 & 05.05 & 16.05 \\
\hline & $\begin{array}{l}\text { Rovral Flo } 255 \mathrm{SC} \\
\qquad 51 \mathrm{ha}^{-1}\end{array}$ & $\begin{array}{l}\text { iprodione } \\
1.27 \mathrm{ha}^{-1}\end{array}$ & - & $16.05 ; 30.05$ & $09.05 ; 18.05$ & $23.05 ; 04.06$ \\
\hline & $\begin{array}{l}\text { Mythos } 300 \mathrm{SC} \\
2.51 \mathrm{ha}^{-1}\end{array}$ & $\begin{array}{c}\text { pirymethanil } \\
0.83 \mathrm{l} \mathrm{ha}^{-1}\end{array}$ & - & 23.05 & 13.05 & 28.05 \\
\hline $\mathrm{V}$ & $\begin{array}{l}\text { Thiram Granuflo } 80 \mathrm{WG} \\
\qquad 4 \mathrm{~kg} \mathrm{ha}^{-1}\end{array}$ & $\begin{array}{l}\text { thiram } \\
3.2 \mathrm{~kg} \mathrm{ha}^{-1}\end{array}$ & - & 10.05 & 05.05 & 16.05 \\
\hline
\end{tabular}



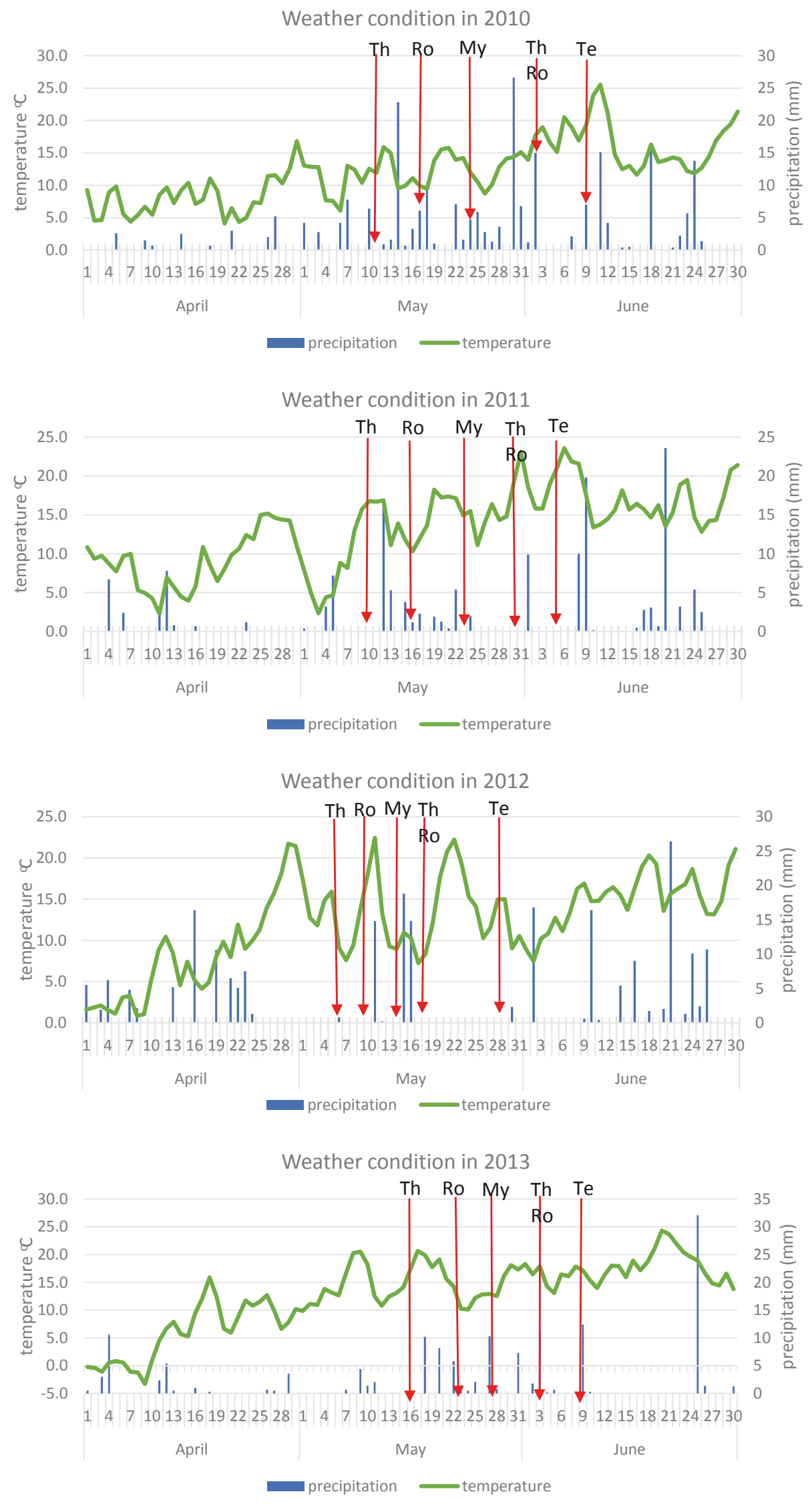

Explanations: Th - Thiram Granuflo 80 WG, Ro - Rovral Flo 500 SC, My - Mythos 300 SC, Te - Teldor 500 SC Arrows mark the terms of fungicide applications

Figures 1-4. Meteorological conditions during strawberry fruit vegetation periods in the 2010-2013 seasons 
treatment was estimated at: II $-5.2 \mathrm{~kg} \mathrm{ha}^{-1}$, III -9.2 $\mathrm{kg} \mathrm{ha}^{-1}$, IV $-6.5 \mathrm{~kg} \mathrm{ha}^{-1}, \mathrm{~V}-3.2 \mathrm{~kg} \mathrm{ha}^{-1}$.

Fruit samples without visible symptoms of any fungal infections were collected to evaluate the effect of fungicides on the quality of strawberries at the harvest maturity stage (I-III treatments). Laboratory analyses were performed to determine the content of:

- extract - by refractometry (PN-EN 12143:2000)

- organic acids - by titration with phenolphthalein (PN-90/A-75101/04)

- total sugars - by the Lane and Eynon method (PN-90/A-75101/07)

- vitamin $\mathrm{C}$ - using the spectrophotometry method (PN-A-04019)

- polyphenols - using the spectrophotometry method (Shahidi and Naczk 1995)

- anthocyanins - using the spectrophotometry method (Wrolstade 1993).

The analyses were carried out at the Department of Food Plant Chemistry and Processing of the University of Warmia and Mazury in Olsztyn.

Strawberries weresampledduring thefirst harvest from each plot treated with the thiram fungicide to determine dithiocarbamate concentrations (II-V treatments). The spectrophotometric analysis was conducted at a detection limit of $0.03 \mathrm{mg} \mathrm{kg}^{-1}$ (2012) and $0.05 \mathrm{mg} \mathrm{kg}^{-1}$ (2011 and 2013) in the Pesticide Residue Analytical Laboratory of the Central Laboratory in Torun.

Data related to the chemical composition of strawberry fruits were processed by two-way ANOVA (the first factor was fungicide treatment, the second, the cultivar), and dithiocarbamate concentrations - by one-way ANOVA in the Statistica 10.0 application. The significance of differences was evaluated by Duncan's test at $\mathrm{p}=0.05$.

\section{RESULTS}

The results presented in Figures 1-4 indicate that weather conditions were generally favorable for strawberry growth throughout the four-year study. Ambient temperature was optimal and exceeded the multiyear average in most analyzed months. The growing seasons (May-June) were characterized by high precipitation. Insufficient rainfall was observed only at the beginning of the growing season in April 2011 and during fruit development in mid-June 2013.

The quality of strawberry fruits in the analyzed period was relatively high, mainly due to the low

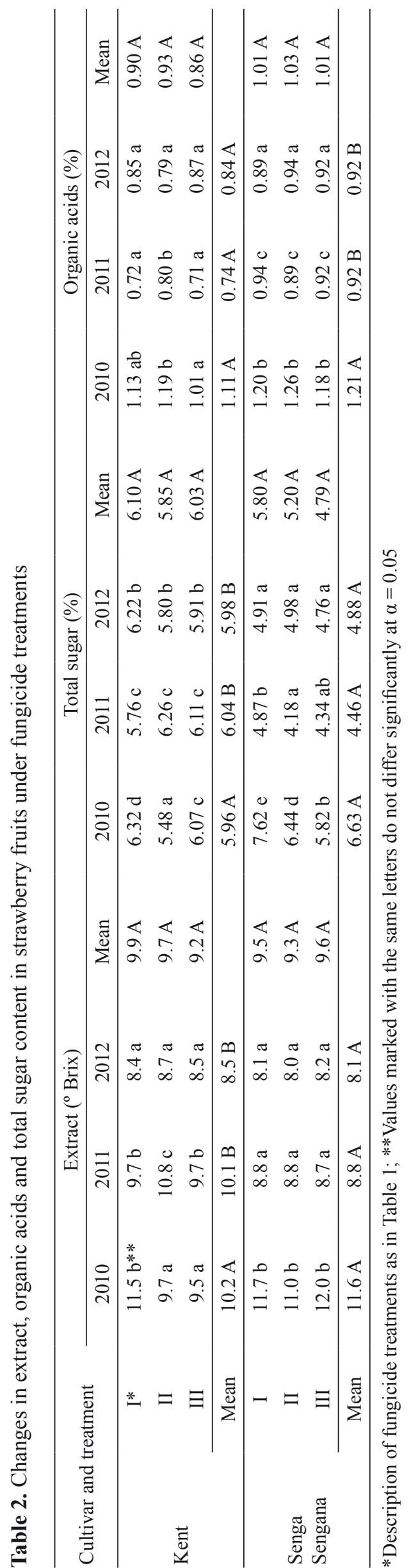




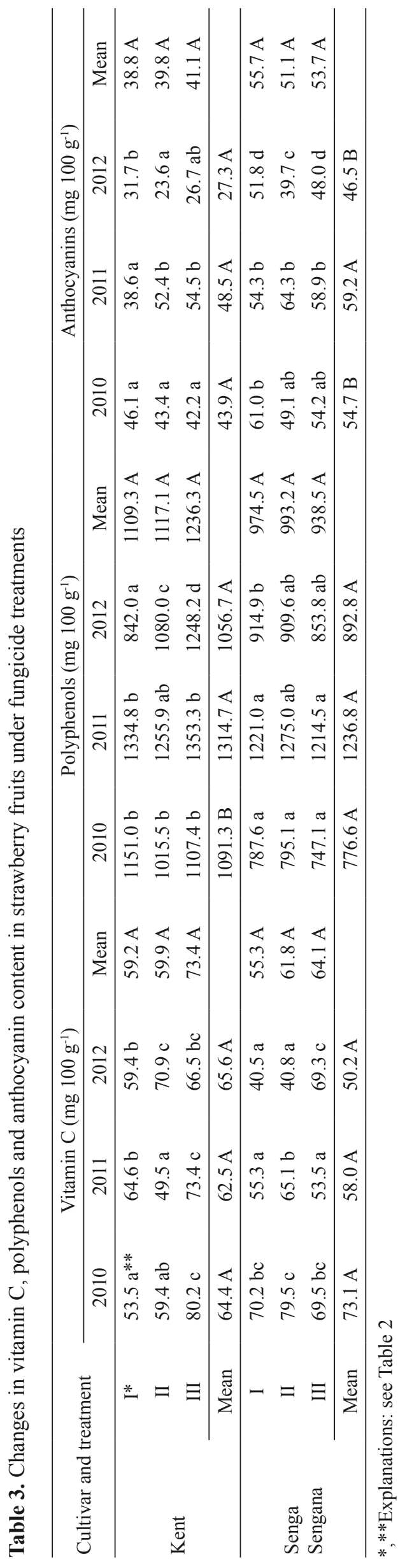

risk of infections caused by Botrytis cinerea. Significant differences in the chemical composition of strawberry fruits were observed between the analyzed cultivars. Differences were noted in the content of extract and total sugars (Tab. 2), which were lower in 'Senga Sengana' than in 'Kent' in two years of the study. Anthocyanin (Tab. 3) and organic acid concentrations (Tab. 2) were higher in 'Senga Sengana'. The applied crop protection agents led to minor variations in the chemical composition of strawberry fruits, and resulted in lower extract content (Tab. 2) and lower concentrations of total sugars (Tab. 2) and anthocyanins (Tab. 3) in 'Kent' strawberries on one sampling date.

Higher concentrations of extract, organic acids (Tab. 2) and polyphenols (Tab. 3) were observed sporadically. The vitamin C content of 'Kent' strawberries increased in treatments with higher fungicide rates in three successive years of the experiment. 'Senga Sengana' responded less readily to higher fungicide rates, but more than a $70 \%$ increase in vitamin $\mathrm{C}$ concentrations was noted on one sampling date (Tab. 3). In two successive years, total sugar concentrations (Tab. 2) in 'Senga Sengana' strawberries decreased in response to fungicide treatment, and a drop in anthocyanin levels was noted on one occasion (Tab. 3).

Dithiocarbamate residues were detected in all samples from the first harvest of strawberries. Their concentration varied widely from 0.04 to 1.31 $\mathrm{mg} \mathrm{kg}-1$ in treatments with a single application of thiram and from 0.33 to $1.46 \mathrm{mg} \mathrm{kg}^{-1}$ in treatments where the fungicide was applied twice (Tab. 4). The maximum permissible fungicide residue levels in Poland $\left(10 \mathrm{mg} \mathrm{kg}^{-1}\right)$ were not exceeded in any of the analyzed samples. However, dithiocarbamate residues were detected in all strawberry samples after 30 days of treatment with thiram fungicide.

\section{DISCUSSION}

Chemical plant protection agents are widely used in strawberry production, but those compounds do not directly influence metabolic processes in strawberry plants. Thus, they exert a less significant effect on the chemical composition and quality of strawberry fruit than other environmental factors (Given 1985). The results of this study validate the above observations. On the other hand, there are many examples given of the good quality of strawberries cultivated without the application of chemical plant protection products. According to numerous authors, food from organic farming 
Table 4. Dithiocarbamate residues in 'Senga Sengana' strawberry fruits

\begin{tabular}{lcccc}
\hline \multirow{2}{*}{ Study year } & \multicolumn{4}{c}{$\mathrm{CS}_{2}$ content $\left(\mathrm{mg} \mathrm{kg}^{-1}\right)$} \\
\cline { 2 - 4 } 2011 & $\mathrm{II}$ & $\mathrm{III}$ & $\mathrm{IV}$ & $\mathrm{V}$ \\
& $0.26 \mathrm{a}^{* *}$ & $0.54 \mathrm{a}$ & $0.91 \mathrm{~b}$ & $1.31 \mathrm{c}$ \\
2012 & $(0.23-0.31)^{* * *}$ & $(0.45-0.61)$ & $(0.85-0.99)$ & $(0.9-1.61)$ \\
& $0.16 \mathrm{~b}$ & $0.33 \mathrm{c}$ & $0.06 \mathrm{a}$ & $0.04 \mathrm{a}$ \\
2013 & $(0.15-0.18)$ & $(0.26-0.43)$ & $(0.6-0.6)$ & $(0.04-0.04)$ \\
\hline Days between last thiram & $0.76 \mathrm{c}$ & $1.46 \mathrm{~d}$ & $0.52 \mathrm{~b}$ & $0.24 \mathrm{a}$ \\
application and fruit harvest & $(0.75-0.78)$ & $(1.44-1.48)$ & $(0.47-0.56)$ & $30.22-0.26)$ \\
\hline Thiram dose in kg ha-1 & $30-34$ & $12-14$ & $30-34$ & $30-34$ \\
\hline
\end{tabular}

$*$, **Explanations: see Table 2; ***Values in the brackets show a range of the studied parameter

is characterized by its higher quality, although some research findings are inconclusive. Higher levels of extract (Nunes et al. 1995), organic acids (Kaźmierczak et al. 2011), vitamin C (Tarozzi et al. 2008, Reganold et al. 2010, Rochalska et al. 2011), sugars (Cayuela et al. 1997, Pirlak and Köse 2009, Esitken et al. 2010, Reganold et al. 2010, Kaźmierczak et al. 2011, Rochalska et al. 2011), anthocyanins and polyphenols (Fernandes et al. 2012) were determined in organically grown strawberries. In other studies, organic strawberries were found to contain less extract, organic acids (Reganold et al. 2010) and vitamin C (Kaźmierczak et al. 2011).

Regardless of the evaluated plant protection systems, the differences in chemical composition do not exert a significant influence on the quality of strawberry fruits, in particular if yield losses resulting from the absence of chemical protection are taken into account. The only exception is contamination with pesticide residues, which shifts consumers' interest to organic foods. The above applies particularly to dithiocarbamates, fungicides which are widely used in fruit and vegetable farming (Thiram Granuflo 80 WG in this study). Dithiocarbamate residues are sporadically detected even in organically grown strawberries (Szymona 2012). A 2012 monitoring study of strawberries in different regions of Poland (Łozowicka et al. 2013, Pszczolińska et al. 2013, Szpyrka et al. 2013) revealed significant variations in dithiocarbamate concentrations in fruit samples. They were determined at 0.05 to $0.75 \mathrm{mg} \mathrm{kg}^{-1}$ and reached the maximum value of $2.9 \mathrm{mg} \mathrm{kg}^{-1}$ in one case. The above contamination levels were similar to the values noted in our studies. According to Łozowicka and Kaczyński (2009), dithiocarbamate levels determined in crops in northeastern Poland (tomatoes, lettuce, sweet peppers, beetroots, apples, currants, strawberries and cherries) do not pose a threat to consumer health.

\section{CONCLUSIONS}

1. In the present study the chemical composition of 'Kent' and 'Senga Sengana' strawberries was not dependent on the fungicide protection level. The only exception was the increase in the vitamin C content of 'Kent' strawberry fruits that had been treated with the investigated fungicides.

2. Minor variations in the content of selected compounds, i.e. organic acids, sugars, vitamin $\mathrm{C}$, anthocyanins and polyphenols were also observed. The nature of those changes could not be determined unambiguously in this experiment.

3. all fruit samples from the first harvest were contaminated with dithiocarbamate residues regardless of the thiram dose applied.

\section{REFERENCES}

Andersson G., RundlöF M., Smith G., 2012. organic farming improves pollination success in strawberries. DOI:10.1371/journal.pone.0031599. PLoS ONE 7(2): e31599.

Bartomeus I, Potts S.G., Dewenter I.S., Vaissiere B.E., Woyciechowski M., Krewenka K.M., et al., 2014. Contribution of insect pollinators to crop yield and quality varies with agricultural intensification. DOI: 10.7717/peerj.328. PeerJ 2:e328.

Cayuela J.A., Viueira J.M., Albi M.A., Gutierez F., 1997. Influence of the ecological cultivation of strawberries (Fragaria $\times$ Ananassa cv. Chandler) on the quality of the fruit and on their capacity for conservation. J. Agric. Food Chem. 45(5): 1736-1740.

Dogheim S.M., Gad Alla S.A., El-Marsafy A.M., 2001. Monitoring of pesticide residues in Egyptian 
fruits and vegetables during 1996. J. AOAC Int. 84(2): 519-531.

Esitken A., Yildiz H.I., Ercisli S., Donmez M.F., Turan M., Gunes A., 2010. Effect of plant growth promoting bacteria (PGPB) on yield, growth and nutrient contents of organically grown strawberry. Sci. Hort. 124: 62-66.

Fernandes V.C., Domingues V.F., De Freitas V., Delerues-Matos C., Mateus N., 2012. Strawberries from integrated pest management and organic farming: Phenolic composition and antioxidant properties. Food Chem. 134: 1926-1931.

Given N.K., 1985. Effect of crop management and environment on berryfruit quality - a review. N. Z. J. Agr. Res. 13(2): 163-168.

Grosicka-MaciąG E., 2011. Biological consequences of oxidative stress induced by pesticides. Post. Hig. Med. Dośw. 65: 357-366.

Hakala M., Lapveteläinen A., Houpalahti R., Kallio H., Tahvonen R., 2003. Effects of varieties and cultivations conditions on the composition of strawberries. J. Food Comp. Anal. 16: 67-80. Available online at http://pr-rp.hc-sc.gc.ca/mrl-lrm/ results-eng.php; cited on 17 Sept 2014.

Kahu K., KlaAs L., KiKas A., 2010. Effect of cultivars and different growing technologies on strawberry yield and fruit quality. Agron. Res. 8: 589-594.

Kalt W., Forney C.F., Martin A., Prior R.L., 1999. Antioxidant capacity, vitamin $\mathrm{C}$, phenolics, and anthocyanins after fresh storage of small fruits. J. Agric. Food Chem. 47: 4638-4644.

Kasperbauer M.J., Loughrin J.H., Wang S.Y., 2001. Light reflected from red mulch to ripening strawberries affects aroma, sugar and organic acid concentration. J. Photoch. Photobio. 74(1): 103-107.

Kaźmierczak R., Hallmann E., TrešČInSKa V., Rembialkowska E., 2011. Estimation of the nutritive value of two red beet (Beta vulgaris) varieties from organic and conventional cultivation. J. Res. Applic. Agric. Eng. 56(3): 207-210.

Keats A., 2013. Thiram strawberry residue study. Horticulturae Australia. Available online at http:// www.horticulture.com.au/reports/search_final_ reports_result.asp?src $=\&$ orgid $=0 \&$ projid $=\overline{62} 65 \&$ st rSearch $=\&$ strProjectNo $=$ BS12024\&strIndustry $=0$ All\&strSortby $=$ date\&strDisplay $=$ titledesc \&page no=1; cited on 10 Sept 2014.

Łozowicka B., KaczyŃski P., 2009. Dithiocarbamate residues in food and the potential risk for consumers. Bromat. Chem. Toksykol. XLII(4): 1155-1160.

Łozowicka B., Hrynko I., Rutkowska E., Jankowska M., KACZYŃSKi P., 2013. Official control of pesticide residues in crop from the north-eastern Poland in 2012. Prog. Plant Prot. 53(3): 571-575.

Miller E., Malinowska K., GaŁęcka E., Mrowicka M., KęDZiora J., 2008. Role of flavonoids as antioxidants in human organism. Pol. Merk. Lek. XXIV(144): 556-560.
Nunes M.C.N., Brecht J.K., SArgent S.A., Morais A.M.M.B., 1995. Effect of delays to cooling and wrapping on strawberry quality (cv. Sweet Charlie). Food Control 6(6): 323-328.

Ohtsuka Y., Kibe H., Hakoda N., Shimura I., Ogiwara I., 2004. Heritability of sugar contents in strawberry fruit in the F1 population using a common pollen parent. J. Japan. Soc. Hort. Sci. 73(1): 31-35.

PirlaK L., KöSE M., 2009. Effects of plant growth promoting rhizobacteria on yield and some fruit properties of strawberry. J. Plant Nut. 32(7): 11731184.

PN-EN 12143:2000. Fruit and vegetable products. Determine the content of soluble substances with refractometry.

PN-90/A-75101/04. Fruit and vegetable products. Determine the content of total acidity.

PN-90/A-75101/07. Fruit and vegetable products. Determine the content of total sugars and nonsugar extract.

PN-A-04019. Foodstuffs. Determine the content of vitamin C.

Pszczolińska K., Rzeszutko U., Domańska I., WlazŁo J., Rolnik J., 2013. The results pesticide residues research in crops from the areas of provinces Silesia and Opole in 2011-2012. Prog. Plant Prot. 53(3): 582-592.

Reganold J.P., Andrews P.K., Reeve J., CarpenterBoggs L., Schadt C.W., Alldredge J.R., et.al., 2010. Fruit and soil quality of organic and conventional strawberry agroecosystems. PLoS ONE 5(9): e12346.

Regulation of Agriculture and Rural Development Minister 2008. Available online at file: //C:/Users/ Admin/Downloads/D20080201.pdf; cited on 17 Sept 2014.

Rochalska M., Orzeszko-Rywka A., Czapla K., 2011. The content of nutritive substances in strawberries according to cropping system. J. Res. Appl. Agric. Eng. 56(4): 84-86.

Roussos P.A., Denaxa N-K., Damvakaris T., 2009. Strawberry fruit quality attributes after application of growth stimulating compounds. Sci. Hort. 119: 138-146.

Shahidi F., NACZK M., 1995. Food Phenolics: Sources, Chemistry, Effects. Technomic Publishing Co: Lancaster. P. A.: 128-136.

SKuPIEŃ K., 2003. Estimation of chosen quality traits of fresh and frozen fruit of six strawberry cultivars. Acta Sci. Pol., Hortorum Cultus 2(2): 115-123.

Sмiтн B.J., 2013. Fruit quality, phytochemical content, and disease severity of muscadine grapes affected by fungicide applications. Pharm. Crop. 4: 21-37.

Szpyrka E., Kurdziel A., Matyaszek A., Podbielska M., Rupar J., SŁowik-Borowiec M., 2013. Pesticide residues in crops from the southeastern region of Poland (2012). Prog. Plant Prot. 53(2): 402-406. 
Szymona A., 2012. Causes of not allowed pesticide residues in plant material of origin of organic strawberries. J. Res. Appl. Agric. Eng. 57(4): 138140.

Tarozzi A., Cochiola M., D`evoli L., Franco F., Hrelia P., Gabrielli P., et al., 2008. Bioactive molecule content, antioxidant and antiproliferative activities of strawberries (Fragaria Ananassa, cultivar Favette) grown by biodynamic and conventional agriculture. Cultivate the Future. Book and Abstracts 16th IFOAM Organic World Congress, 16-20 June, Modena: 102.

Wrolstad R.E., 1993. Color and pigment analyses in fruit products. Oregon State University, Agricultural Experiment Station, Station Bulletin No 464.

Received August 20, 2014; accepted November 19, 2014 